Hee Sook LEE-NIINIOJA

Oksfordo Brukso universitetas

\title{
Religious and Intercultural Influence on Mozarabic Capitals in the Saint-Pierre Abbey Church Cloister, Moissac (1100)
}



Muasako abatijos bažnyčia (1100 m.) - vienas ryškiausių prancūzų romaninio meno pavyzdžių. 46 iš 76 kapiteliụ atspindi biblinius ar šventụjų gyvenimo siužetus. Kiti 30 kapitelių dekoruoti gèlių motyvais, tai daugiausia tikroviški arba stilizuoti akantai. Penkiuose kapiteliuose pavaizduoti mozarabiško stiliaus akantai. Akantas - Viduržemio jūros regiono augalas, krikščionybèje simbolizuojantis nemirtingumą ir skausmą / nuodèmę / bausmę. Šio augalo motyvais buvo dekoruojami korintiniai kapiteliai viduramžiais. Vëliau akantas tapo amžinybę simbolizuojančiu islamo arabeskos elementu.

As a leading example of French Romanesque art and the oldest surviving one, 46 of the 76 cloister capitals at the Abbey Church in Moissac (1100) illustrate themes from the scriptures or the lives of saints, and the remained 30 display floral images, mainly acanthus - natural or conventionalized. Five capitals are to bear a Mozarabic acanthus style. Acanthus is a Mediterranean plant whose hidden meaning was immortality and pain/sin/punishment in Christianity. It decorated on Corinthian capitals as a supporting motif in ornamentation during the Middle Age, while it became the Islamic arabesque, symbolising "infinity" due to its never-ending feature.

\section{Preface}

The paper has two aims for discussion. It deals with religious and intercultural relationship between Mozarabic acanthuses in medieval Europe, by comparing the Cloister of the Abbey Church, Moissac, and other cloisters along the Pilgrimage Routes of Santiago de 
Compostela. The paper also examines the function of acanthus in general, either symbolic or aesthetic or both.

I have very specific reasons for this effort ideologically and personally. First, during my residence in Kuwait and Indonesia from 1998 to 2007, I experienced uncountable conflicts between Christians and Muslims. Myself as a Christian, I invented a strategy of communication with Muslims through commonness in culture between two religions. It was acanthus, appeared both in Christian and Islamic religious buildings. And arabesque, a version of the acanthus, is an important means in Islamic ornamentation. Second, my personal attachment to the acanthus took place during my conversion to Christianity. In fact, lotus - the symbol of the Enlightened Buddha - had affected my earlier Buddhist faith in my home country, Korea, and this visual effect continued when I had my first glimpse of the acanthus at Canterbury Cathedral, even leading to my engagement at medieval studies in sincerity. Anyhow, an excellent example for this discussion was found in Mozarabic acanthus whose history was blended with Christian and Islamic culture.

In order to do so, some information on Mozarabic architecture is necessary. This architectural style was created by Christians who lived in the Iberian Peninsula after the Muslim conquest in 711. Mozarabic art became a synthesis of the two traditions. The subject matter is Christian, but the style displays the assimilation of Islamic decorative motifs and forms. Through the emigration of Mozarabs to the north, Islamic influence in architecture spread further into the rest of Europe. One characteristic is the application of column as support, crowned by a Corinthian capital with the stylized vegetal - called "arabesque". Although the influence of Spanish culture on Islamic architecture was felt soon after their invasion to Muslim areas, Islamic buildings had to borrow Visigothic existing elements, because Islam civilization was still in its infancy. The Mosque of Cordoba (785) can testify a new Islamic style.

Moreover, for the transmission of Islamic motifs into France from Spain, the Pilgrimage Routes played a key role in religious and cultural exchange and development between them during the later Middle Ages. Romanesque artists began to reuse the Corinthian capital and adopted the monumentality of classical decorative schemes. The churches of Saint-Sernin in Toulouse, Saint-Pierre in Moissac in France, Léon, and Compostela in Spain along this Routes show the same taste for classical antiquity. Acanthus leaves were often decorated with balls and pine cones. To this, interlace was added.

\section{Symbolic and Aesthetic Ornament}

Historically the viewer infers an underlying meaning and looks for an interpretation at all kinds of ornamentation. Termed "symbolic content", it mediates between recognisable reality and the invisible realm. The more the content of the work was expressed through its aesthetic perfection, the greater its symbolic value became for worship. The Renaissance theoretician Alberti (1404-72) proposed that the ornamentation on buildings convey feelings of majesty, authority, and dignity. By moving the passion of the spectator through their architectural splendour, buildings persuade the viewer to feel the majesty of God or the dignity of the State ${ }^{1}$. 
In all decorative arts, Hulme divides into two groups - symbolic and aesthetic. The former has been chosen for their significance; the latter for their beauty. The ornaments of ancient Egypt and Assyria were sacred and mystic, sanctifying daily life and raising noble emotion. Some plants imply both, as the symbolic connection enhances the meaning and interest to decoration. As the relationship between specific plants of magical qualities and gods shared with the primitive mentality of antiquity, paganism was interpreted into an association of saints and plants ${ }^{2}$.

The most popular example is the lotus. Despites its use for decoration, a growing sense of beauty brought the attribution of symbolic content as the embodiment of all life, arising from the depths of the water, the void. The open form of flower and its expansion represent the wheel with its rays flowing out from the centre. In Islamic concept, flower gardens are associated with Paradise and the abode of souls.

Another case is the tree. Its root grasps into the mysterious earth; its trunk as the pillar of dwellings; and its branches stretches in the sky, the celestial. The tree is the image of bridging heaven and earth with a symbolic value of 'the axis of the world'. Symbolic trees appeared on the Cluny hemicycle Romanesque capitals. Here, the symbolic element is an agent between the identifiable reality and mysterious domain of religion, philosophy, and magic, extending the conscious understanding into the unconsciousness. Medieval ornaments are not simply aesthetic, but are likely symbolic. As a suitable candidate for the examination, acanthus, developed in Greece (BC 4C), was never out of use, even covering up a join and filling an awaked space.

\section{Acanthus}
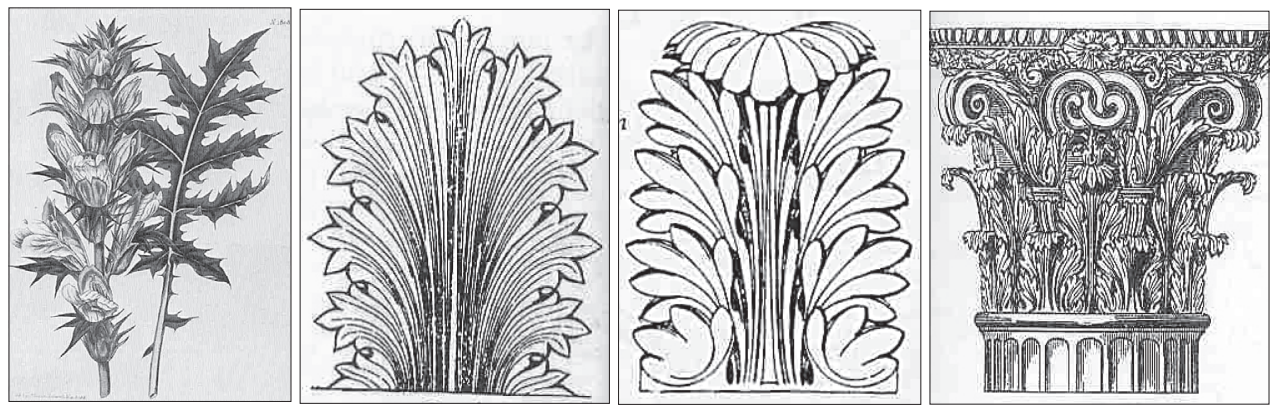

Figure 1. Acanthus leaf; Acanthus spinosus; Acanthus mollis; Corinthian capital

The plant acanthus weaves its coils, a brilliant sight to see, whose marvel will delight your soul (Theocritus).

Acanthus (see Figure 1) is a Mediterranean plant with spiny leaves, and its conventionalised representation has decorated on Corinthian capitals since Greco-Roman times. It has a large leaf with a broken edge. Two principal species are acanthus spinosus and acanthus mollis. The former has narrow, spiky, and pointed lobes of the Greek origin, 
while the latter is broad, blunt, and soft of the Roman. Its name was derived from Greek akantha (thorn), probably due to akĕ (sharp point). The motif started to support plantlike volutes in architectural enrichments and to form the calyx from which spiral scrolls arise. It has been formalised, simplified, and modified in a variety. The deeply serrated and scalloped leaves and strong, graceful, curving stems of this European plant inspired the formalised decorative motif. Acanthus spinosus was used on Greek, Hellenistic, and Byzantine capitals; Acanthus mollis on Roman, Romanesque and Early Gothic ones.

Cooper claims that acanthus represents life, immortality, horns of the lunar crescent, veneration of the arts in Mediterranean countries. As the motif showed first in the Greek monumental art, often on burial urns in association with the death and morning, a definite relationship between the plant and the tomb is to be existed ${ }^{3}$. The Roman architect Vitruvius' story of the acanthus related to the female and funerary is well-known. Phrases in Greek mythology indicate a sepulchral significance of the plant, because thorny and barbed bushes and herbs were often considered to be plants of bad omen under the power of the underworld, and used as a common means for prohibiting dead people from returning to haunt the earth ${ }^{4}$. The first Corinthian column was placed at an internal Ionic colonnade as a cult statue, becoming an object of worship. The acanthus capital at Temple of Apollo, Bassae suggests a role in cult.

Despite its symbolism, the ornamental acanthus has kept longer popularity, as its earliest examples were added to the palmette for a visual effect. During the Hellenistic period, acanthus had a firm position, exploiting affluent imagination, first on funerary stele, and later on capitals, testified on the column topped by a group of three dancing girls from Delphi (3C). As an architectural enrichment, acanthus spread further to the Roman, Byzantine and Romanesque capitals until it turned into Gothic foliage. It also became part of Buddhist art, while it developed into an intricate and varied ornament of arabesque in Islamic world. Among them, it was on Romanesque capitals which acanthus played its best aesthetic role. Cluny hemicycle capitals, an allegory of the monastery as a spiritual gymnasium, had the absolutely decorative Corinthian ones. Acanthus implies both significance and beauty, although Hauglid argues acanthus as decoration, saying that "What perhaps was once the symbol of death became later on the life of life in European ornamentation"s.

\section{Romanesque Capitals (8/10-12C)}

The term "Romanesque" merged in the early $19^{\text {th }}$ century in Normandy when high enthusiasm for monumental archaeology and the rediscovery of medieval art. In 800, Charlemagne was crowned as the Holy Roman Emperor, and a new centre started at Aachen, constructing monasteries. Its architecture is the first pan-European architectural style. Combining Roman and Byzantine features, Romanesque is known by its massive quality, thick walls, round arches, sturdy piers, groin vaults, large towers and decorative arcading. As column is an important structural feature for structure and decoration, sculpted decoration became the main characteristics of Romanesque buildings. France and Spain were centres. During this period, acanthus reappeared in much of its old form, and its tendril 
is often schematically treated. The influence of Lombard shared as well. The capitals were the Corinthian type with a heavy abacus and modified proportions and details.

The Romanesque capital was derived from a simple variant of the cushion (pyramidal) capital and ended to the figural ones. The Ionic capital with its volute was an early adaptation, but the adornment of spiral and floral patterns turned the cushion capital into an ornamental one. Into this, masks and animal shapes, later figurative scenes, were added to highlight the figural capital. Hearn underlined that Romanesque capitals started from the substituting non-religious decorative motifs for the foliage on the Corinthian capital with the plasticity of conception and the depth of carving. Indeed, the most prominent characteristic of the Corinthian capital is the sculptural quality of its structure ${ }^{6}$.

Sculpture on capitals was due to the following context. As architectural intermediary, the capital is the upper part of a column and supported the vault. The symbol of the column (base/earth - capital/heaven) derives from the shape of trees (roots-crown). As this correlation has always existed in the sacred sphere, the column and vault bore the symbolical form of the cosmos, where God lived. The human figure capital appeared at SaintBenoit-sur-Loire, displaying a transition from the Corinthian to figured capital.

Romanesque art was to make the church 'speak', space had to be found for an abundant iconography, without disturbing the architectural masses and their functions. It was necessary to set on top of the columns, at the same time avoiding the appearance of meagreness and insignificance, not one or two figures. ${ }^{7}$

To understand the function of decoration on Romanesque capitals, the context of medieval culture and art should be examined. One crucial document is a passage in the "Apologia" to William of Saint-Thierry (c. 1125), written by St. Bernard of Clairvaux (10901153). According to St. Bernard, all these deformed animals will destroy the mediation of the law of God, because monks will spend the whole day looking at these things. Architectural sculpture was served by the church as a means of mass-communication, addressed to increasing, but largely illiterate public. Focillon has rather a different explanation. The problems set by the decoration of the capital were more complex, since a form was determined by a function. The use of figures for highlighting and helping such functional activity was perhaps the utmost achievement of the Romanesque sculpture ${ }^{8}$.

Schapiro shares his view with Focillon. Various designs of the Romanesque capitals mark the first pervasive example of constantly individualized ornament on repeated architectural elements. In the $11^{\text {th }}$ century, this differentiation was not used for didactic purposes in the religious themes, and the non-religious motifs have no explicit meaning. If no precise meaning was found, then the purpose is basically to decorate. The aim of sculpted capitals was paralleled to that of the marginal embellishment of medieval art in general. Almost every great work of the Middle Age has a similar frame of decoration, either it be floral, animal, figural, or abstract in design. For example, the Abbey Church of Saint-Pierre-et-Saint-Paul in Cluny (c. 1100) has two capitals bearing eight personifications of the notes of Gregorian chant. Here, the Corinthian capital is an absolutely pure decoration ${ }^{9}$. 
The contrast between the main theme and the decoration, often very marked, served to heighten the meaning and visual effectiveness of the principal subject. From this widespread practice it is safe to infer that the contrast was intended to make the work of art more striking and more impressive. ${ }^{10}$

In France, Romanesque architecture has two stylistic groups. The first (later 11C early 12C) showed on the Pilgrimage Routes, such as Saint-Sernin in Toulouse, Saint-Foy at Conques, Saint-Martial at Limoges and Saint-Martin at Tours. The second (first half of 12C) was in southern and western France, supposing a direct link of Islamic or Byzantine architecture, such as cathedrals of Perigueux, Cahors and Angouleme, and monuments in Limousin, Saintonge, Perigord, Guyenne, and at Moissac (Quercy).

\section{Cloister of the Saint-Pierre Abbey Church, Moissac (1100)}
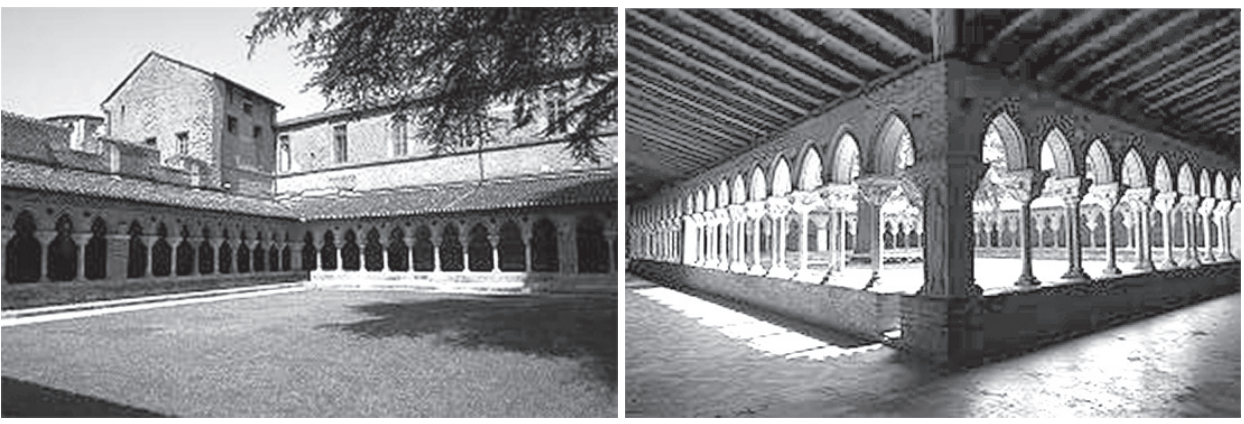

Figure 2. Moissac cloister

Moissac is a town and commune of the Tarn-et-Garonne in south western France. The Saint-Pierre Abbey Church, Moissac is located at the Routes of Santiago de Compostela. According to a legend, the abbey was built by a Frankish king, Clovis, but history says that Saint Didier, bishop of Cahors, founded it in the middle of the seventh century. The $11^{\text {th }}$ and $12^{\text {th }}$ centuries witnessed the first golden age when Moissac was affiliated to Cluny (1047) and its Reformation under Abbot Durand de Bredons (d. 1072). However, its secularization in 1626 forced the Benedictine monks to leave the cloister, replaced by Augustinian canons. In 1793, the French Revolution put an end to monastic life, and was later transformed to saltpetre factory. During its reconstruction (1804-47), the cloister was saved, and listed as a World Heritage now.

The Moissac abbey has the oldest example of Romanesque cloister (1100) with carved figurative decoration (see Figure 2). Aymeric's chronicle reports that the cloister and the sculptures of tympanum were completed in the time of Abbot Ansquitils (1085-1115). The porticoed galleries are composed of marble colonnettes, alternately single and coupled, capped by sculpted capitals with geometrical, plant and animal motifs. Classical fleurons combined with a design of plant stems and foliated scrolls cover the two rows of leaves on the bases of the capital. Of 76 capitals, many have Latin inscriptions explaining the scenes. 46 depict of the Old Testament, the life of Christ, the Apostles, other saints, 
and the Apocalypse; 30 are purely decorative floral - acanthus, palmette, and animal. All combined in a random order without a logical chronology.

When the cloister of Moissac was completed, a few sculptors undertook a further series of capitals for the priory of La Daurade, an abbey near Toulouse, which belonged to Moissac. This illustrates how an iconography peculiar to the Romanesque cloister was emerging in the very late $11^{\text {th }}$ and very early $12^{\text {th }}$ centuries. The inevitable association of architecture and sculpture soon extended to the whole of the mature Romanesque style. Sculpture pervaded capitals, facades, cloisters and the church architecture, welcoming the faithful and outlining the essential elements of the Christian liturgy. It was the same time of the tympanum as a creation of a sculptural synthesis of the Christian doctrine: the church's vision of the ordering of the world. A façade lacking sculpted decoration was incomplete. The Romanesque sculptor placed his art at the service of God for his glory, thus he was highly appreciated by the society of his time. To this, the Pilgrimage Routes played part in the progress of an iconographic programme.

\section{Capital 12: Stylised arabesque, plaits}
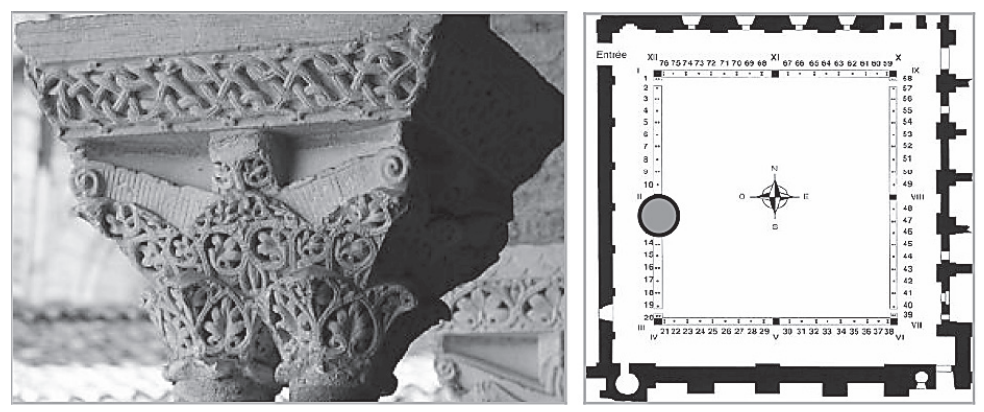

The capital has arabesque style, forming with $\mathrm{nr} 41,61,70,75$ as a group. In the impost block, the echinus has refined and intricate plait pattern, while the abacus has a triple division without ornamentation. Arabesque was identified during the $19^{\text {th }}$ century as the primary characteristic of Islamic ornament. It is a distant relation of acanthus and vine scroll from the eastern Mediterranean area before the advance of Islam. In Stilfragen (Problems of Style, 1893), Riegl limited the term "arabesque" to a stylised form of the vegetal, regarding it as the original creation of the Arab spirit. Its basic feature is geometrisation of the particular vegetal stems, growing from one another infinitely in any direction, instead of branching off from a single continuous stem ${ }^{11}$. Kühnel also argued arabesque as the most expressive artistic manifestation in Islamic art, stressing its pure decoration. Its two aesthetic principles are rhythmical/harmonious movement and filling the entire surface $^{12}$. On the contrary, Sufi scholars Ardalan and Bakhtiar held that arabesque recreates the cosmic processes of the Creator through nature. Its rhythmic component reflects movement, manifests time, and symbolises the infinity, glorifying the concept of 'Garden of Paradise.' Combined with geometry and calligraphy, it exhibits harmony of unity and multiplicity ${ }^{13}$. 
Guilloche (plait/interlace/knot/twist/cable) can be traced back to the beginning of the Neolithic period when pottery started. Twisting and plaiting fibres to make cord and baskets was the earliest human activities, incidentally creating decorative patterns for other materials. Wilson suggests that they do not have symbolism except few ${ }^{14}$, but Cooper rejects this that the nature of the spun thread comprises the mystery of infinity and unrolling of life. For him, they are beautiful, yet mysteriously entangled. As the same character with guilloche, interlace has an important symbol, as it lacks any endings or beginnings - the eternal recurrence, while knots mean continuity, connection, a covenant, and Fate which binds man to his destiny. Moreover, loosening knot is freedom, salvation, and the solving of problems. In Christianity, the three knots in the monastic girdle are said to be the three vows of poverty, chastity, and obedience. It wonders whether any Romanesque sculptors would have understood all the concepts behind motifs, and then applied them to his capitals. Anyhow, plaited pattern was typical Roman, but later Romanesque adopted $\mathrm{it}^{15}$.

\section{Capital 41: Stylised arabesque, spiral rosettes, inscription}

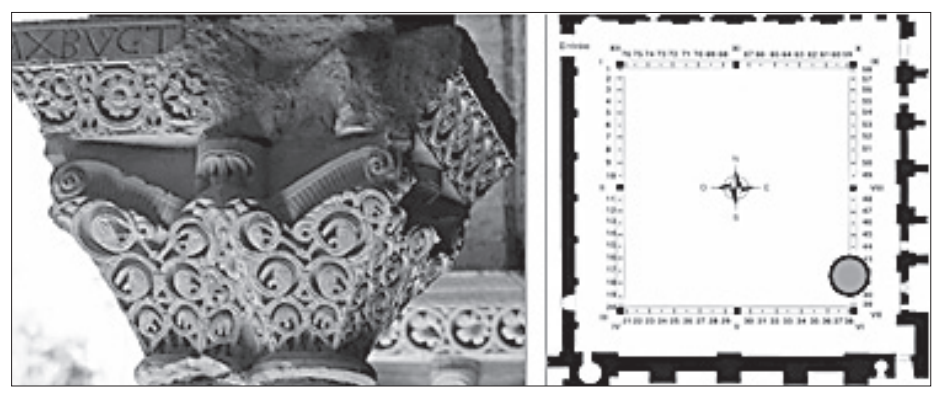

A description of the capital and its meaning was done by Schapiro ${ }^{16}$. On the twin cylinder capitals, a spiral motif is absolutely arabesque, a Byzantine-Islamic reproduction. In the spiral form the centre stands out, and the parallel circles produce rotation and agitation. The spiral is an ancient sign of the sun and life, and its constant rotation symbolizes the pulsation and periodicity of all life. The capital testifies a highly qualified work, illustrating the double meanings of ornaments (decoration and order) in the medieval times. The echinus has stylised spiral rosette, while the abacus has inscriptions, beginning on the passage side (ABCDEFGHI), then the north (KLMNOPQRSTVZA) following Psalm verse 54.3. It continues on the court (NOMINE TUO SALVUM: Help me, God in your name!), and leads to the south (AXBVCT). The letters at the beginning and the end exchange each other, and finally four letters (MLYZ) stand on the passage side. The alphabet is a manifestation of God. On the south, letters begin logically with A (symbol for the start) and followed $\mathrm{X}$ instead of $\mathrm{Z}$ as the ending (symbol for Christ's aim to all things understood). The Latin X corresponds to Greek Chi, the beginning letter for the name of Christ. 


\section{Capital 61: Stylised arabesque, goats and lions}

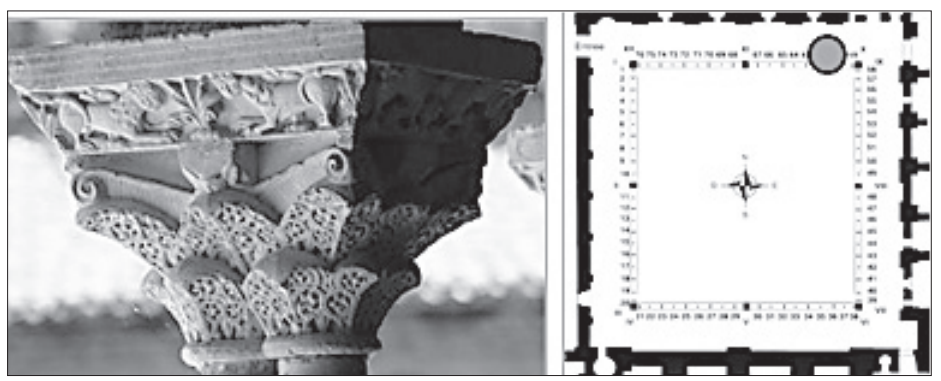

The capital has arabesque foliage in two rows one over the other. It is related to nr 12 in terms of Islamic art. In the impost block, two goats are on the shorter side of the echinus; a pair of lion on the longer side. The abacus has three divisions. Cooper explains in his An Illustrated Encyclopaedia of Traditional Symbols (1978) that goat symbolises masculinity, vitality, and creative energy. Its living on high places means superiority. In Christianity, it is the Devil, the dammed, sinner and lust. The scapegoat is Christ burdened with the sins of the world. Interpreting animals in terms of medieval symbolism can be extensive, depending upon their roles. Romanesque capitals were keen to this.

\section{Capital 70: Stylised Mozarabic arabesque, leaf scroll, Kufic}

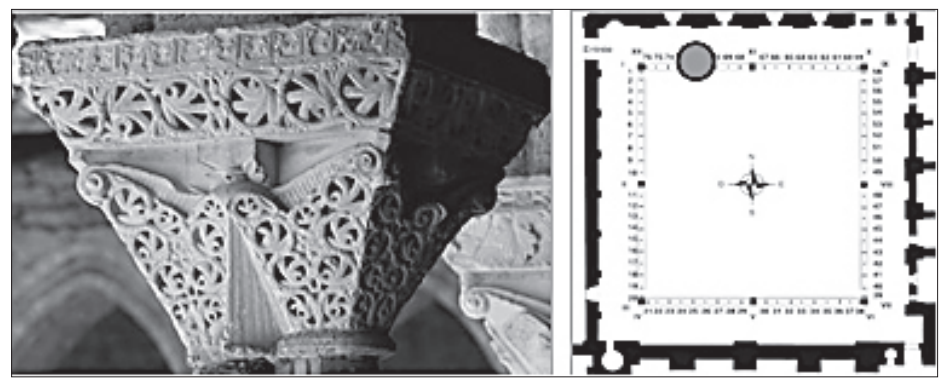

The double capital has Byzantine-Islamic foliage like $\mathrm{nr} 41,61$ as a group. In the impost block, the echinus has a spiral band with flat leaves. The abacus takes an unusual vegetal ornament, repeated a small perpendicular stroke against each other. In fact, it is an Arabic Kufic script and is the only cloister capital in the whole French Romanesque architecture where Arabic script displays. There are three further places in France. According to the Latin translation, a call to Allah, the God of Islam, was repeated: south (HLLAHAL), east (HLLAHLLA), west (HLLAALLH), north (LLAALLH). It has been known that Islamic calligraphy is a major vehicle for aesthetic energies and symbolic meanings, because the word of God is recorded in the Holy Koran. Its two main styles are Kufic whose name was derived from Kufa city in Iraq, and has a rectilinear and angular form for decoration, 
while Naskhi (meaning "cursive") was used for everyday writing. Calligraphy is considered 'the geometry of line', due to its mathematical calculations. Spiritual geometry means both the structure of calligraphy and the whole essence and spirit of Islamic art. A Sufi belief in awareness of God's presence and purpose in His creation is exemplified in iconic form in the art of calligraphy ${ }^{17}$.

\section{Capital 75: Stylised Mozarabic arabesque, leaf scroll, chevron}
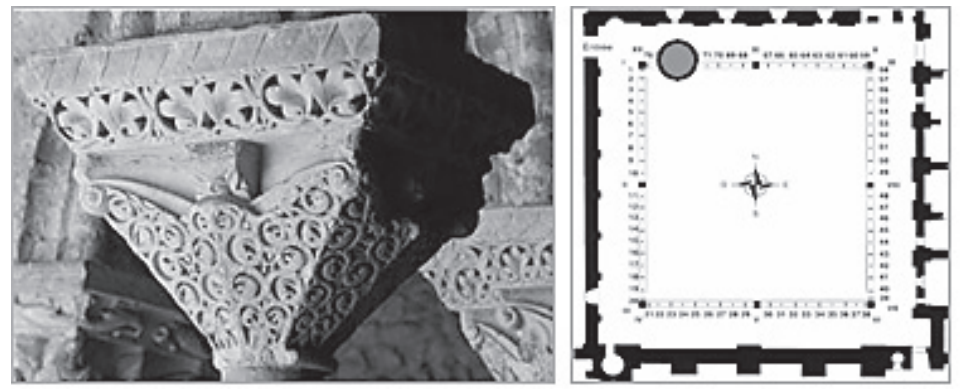

The capital has Mozarabic ornament like nr 41, 61, 70. In the impost block, the echinus has twin pairs of leaves, and the abacus with the chevron motif. Its stylized representation as the Tree of Life could be a symbol of fertility. Triangle (chevron) is the threefold nature of the universe (heaven/earth/man, father/mother/child, man as body/soul/spirit, the mystic number three). The equilateral triangle depicts completion. The upward-pointing triangle symbolises life, fire, masculinity, the spiritual world, and the trinity of love/truth/ wisdom, it denotes royal splendour. In Christianity, the equilateral triangle means the Trinity in unity, and the equality of the three persons.

As briefly mentioned earlier, the term "Mozarabic" is designated the architectural form and all of the related art constructed in Christian territory in the Iberian Peninsula. Three main religious groups lived with tolerance, despite crashes in between. Muslims composed of ethnic divisions (Berbers/Arabs), Mozarabs, and emigrated Jews from remains of the Roman Empire. Mozarabs (from musta'rab meaning "Arabized") are Iberian Christians living in Al-Andalus, the Muslim conquered territories from the Arab invasion (711) to the $11^{\text {th }}$ century. They preserve not only their religion, traditions, and some ecclesiastical and judicial autonomy, but they also adopted Arab customs. Most Mozarabs lived in the large cities, such as Cordoba (the seat of the caliphate), Toledo and Granada, and these attachments caused conflict in the middle of the ninth century. A group of Christians in Cordoba sought martyrdom by insulting the faith of the Muslims. Following a number of uprisings, Mozarabs lost their rights and began to move to the liberated northern areas - Asturias, Léon, and Galicia. This immigration could explain the presence of Moorish-influenced architectural elements (chisel-curl brackets and horseshoe arch) in the northern Spain. The Mozarabic period came to a close with the fall of Toledo to the Christians in 1085. 


\section{Pilgrimage Routes between France and Spain}

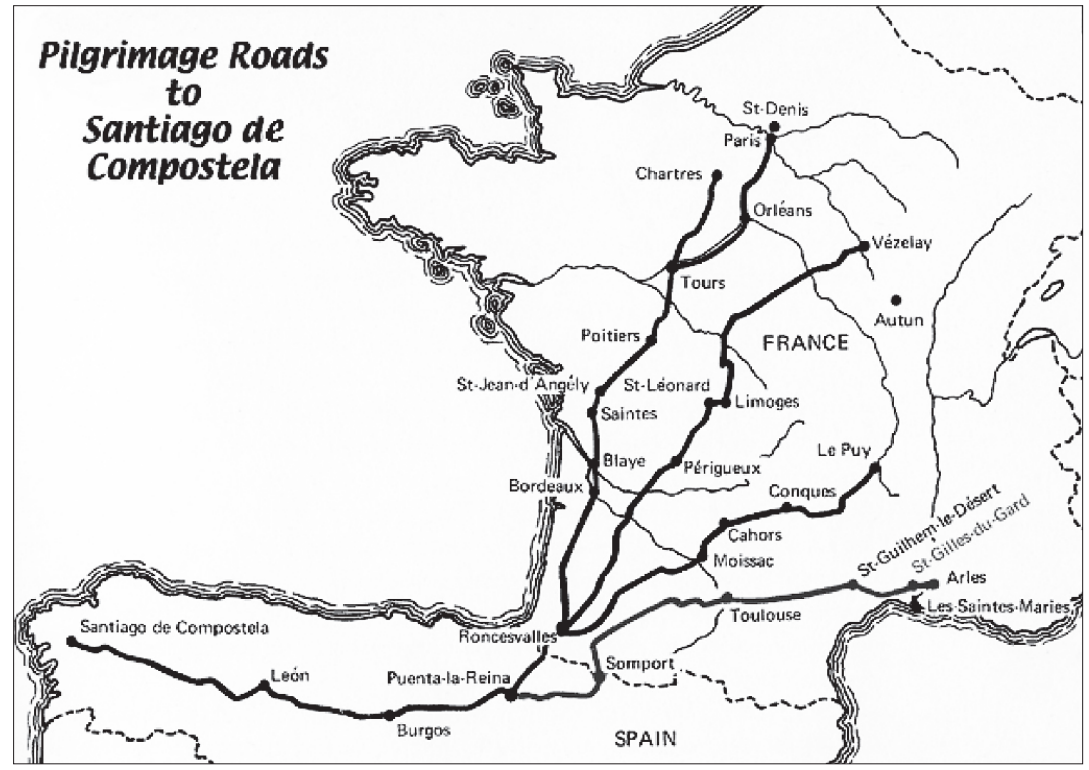

Figure 3. The four principal pilgrimage roads to Santiago de Compostela (Photo: AICT/Allan T. Kohl)

The Middle Ages were a time of pilgrimage - a journey to sacred places - especially during the $11^{\text {th }}$ and $12^{\text {th }}$ centuries whose phenomenon attained uniqueness in Christian civilisation. The Pilgrimage Routes of Santiago de Compostela played a key role in religious and cultural exchange and development, as pilgrims wished to visit the burial place of Saint James at Compostela.

From the $10^{\text {th }}$ century onwards, pilgrims have made four traditional Routes (see Figure 3). According to the $12^{\text {th }}$ century Pilgrim's Guide attributed to Aimery Picaud, Tours (Paris), Vézelay, le Puy-en-Velay and Arles were named as the assembly points for pilgrims coming from all over Europe, including Britain and Ireland. Each of these was the site of a shrine celebrated in its own right, at which the pilgrims would worship before proceeding. The stages of these Routes were marked by further shrines competing for patronage, relics, the interest of the pilgrims, and the business they brought with them. Monasteries and hospices were built along the way to meet the needs of pilgrims as well. In northern Spain, these four Routes merged to become the camino frances that passed across Castile, through Burgos and León to Santiago de Compostela. The Routes was declared the first European Cultural Routes by the Council of Europe in October 1987; it was also named one of UNESCO's World Heritage Sites. Romanesque architecture and sculpture marked its glory through these Routes.

It is no wonder why the capital samples of Nogal de Huertos, San Pedro Loarre, San Martin Frómista and Saint-Pierre Moissac resemble each other (see Figure 4). 

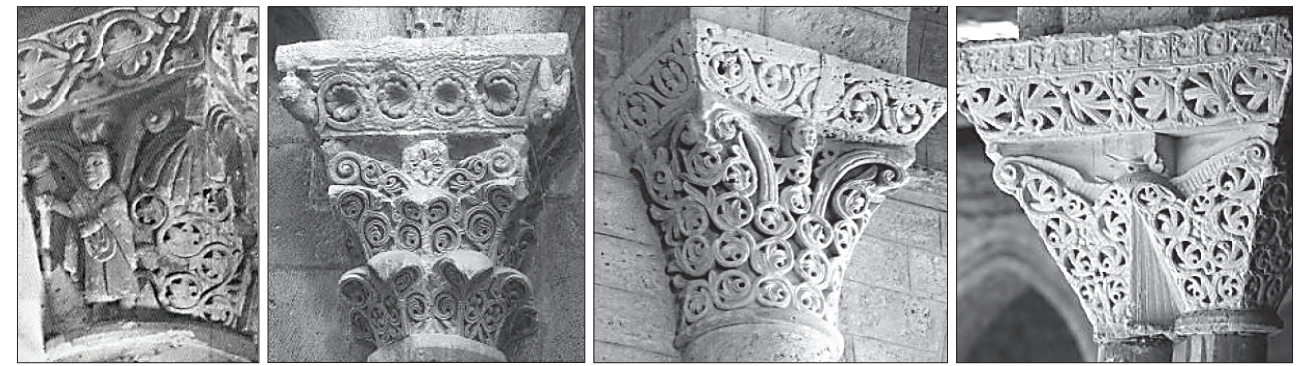

Figure 4. Romanesque capitals along the Pilgrimage Routes (Nogal de Huertos, San Pedro Loarre, San Martín Frómista, Saint-Pierre Moissac)



Figure 5. Re-drawing after K. Watson (Watson K. French Romanesque and Islam: Andalusian Elements in French Architectural Decoration c. 1030-1180. Oxford: BAR International Series. 1989)

Watson in her French Romanesque and Islam (1989) relates that the late $11^{\text {th }}$ Romanesque art rediscovered classical sculpture. Artist began to reuse the Corinthian capital and adopted the monumentality of classical decorative schemes. The key direction taken by $12^{\text {th }}$ century Romanesque sculpture gained a broader prevalence by diffusion along the Routes. In France, Languedoc was most influenced by the decoration at Toulouse. In Spain, the sculpted decorations of camino frances churches are clearly related (Santiago de Compostela, San Isidore in Léon, San Martin at Frómista, Pamplona, Jaca). To these, buildings (San Juan de la Pena, San Pedro Loarre, San Salvador at Nogal de Huertos, Saint-Sernin Toulouse, Saint-Pierre Moissac) are added on the French side of Pyrenees ${ }^{18}$. 
A direct contribution to the similarity of Romanesque capitals can be argued through a historical contact between Moissac, Toledo and others (see Figure 5). Bernard of Sedirac was monk of Moissac and archbishop of Toledo since the capture of the city by Alfonso VI of Léon (1085). He made an effort of crusade in the Holy Land; instead he was absolved of his vow by Pope Urban II (1096) as he passed through Rome. On the way he recruited a number of monks from the monasteries of his native province to staff his administration. From Moissac he enlisted Geraldus, appointing him as cantor of Toledo, then as archbishop of Brage. The features which characterise the Moissac capitals unique in Romanesque sculpture show how artistic relations between France and Spain were close.

As mentioned before, after the completion of the Moissac, a few sculptors participated to a further series of capitals for the priory of La Daurade, an abbey near Toulouse, of which Moissac took care. Soon it extended to the mature Romanesque style along the Routes. In this way, a relationship between San Pedro Loarre and Moissac could be established. Loarre was built inside the castle at the end of the $11^{\text {th }}$ century during a second building campaign. But in the absence of the abbey's archives which was lost during the Revolution (1793), only fragmental history of Moissac's relation with Spanish affairs remain.

Indirect contributions to the similar Romanesque capitals can be suggested through contacts between France and Spain. First, Ferdinand I (1000-1065), the king of Léon and Castile initiated a relationship with Cluny in France. Second, his son, Alfonso VI's (1049-1109) second marriage to Constance of Burgundy was partly arranged through the influence of the Cluniac Order. She was niece of Abbot Hugo. Alfonso is said to have introduced the Order in Sahagun, Spain, choosing a French Cluniac, Bernard, as the first Archbishop of Toledo after its 1085 conquest from Taifa Toledo in assimilation of Christian Castile and Islamic Toledo. Third, Peter the Venerable, Cluny Abbot, visited Toledo (1142) to translate the Holy Koran, bringing Islamic culture back to home. Lastly, Moissac belonged to the Cluny.

\section{Conclusions}

The five Mozarabic capitals in the Cloister of the Saint-Pierre Abbey Church, Moissac were compared with the similar ones in other buildings along the Pilgrimage Routes. Based on the comparison of their visual images and historical backgrounds, the Moissac capitals seemed to be (1) made by the local creativity along the Routes, (2) inspired by Mozarabs who inherited Visigothic heritage, but (3) strongly influenced by the Islamic Umayyad arabesque, (4) whose art was partly originated from the Byzantine tradition.

Although I am part of those scholars who are eager to verify the origin of Mozarabic capitals, I am more ambitious to take this finding as an excellent intercultural approach across space. In other words, despite its regional and unique Romanesque style in Moissac, the five capitals expressed flexible and tolerant attitudes in ornamentation at that time beyond religious ideologies.

This raises another thought. It is that the commonness of Mozarabic capitals along the Pilgrimage Routes could enhance dialogues in current conflicted societies, because 
of different beliefs at present. For my view, much discussions of our common past on visual culture have more advantages than disadvantages, if we are ready to be empathetic. They can bring our longer reflections than our shorter annoyance. Past is a springboard for future. I can prove this: I have pleasant memories in Kuwait and Indonesia for these interesting nine years, calling me to return there all the time.

Referring to the function of the acanthus, the motif seems to act as visual pleasure for believers' eyes as well as mediation for their minds, whether it accompanied animals, geometrical motifs, etc., even without any.

Finally, a church has its own sacredness of the site on which it was built, creating its own style for rituals, celebrations, martyrdoms, or whatever is needed. And its cloister displays the most evident form with multiple meanings. It has a passage whose metaphor is a change from the profane to the sacred world, in order to return to the realm transcendent and immanent - where God is waiting for us. The cloister has also pillars, joining heaven and earth as the world axis. On these pillars, Tree of Life is growing. To this, acanthus has its role as its member.

The Cloister of the Saint-Pierre Abbey Church, Moissac will be at a spiritual crossroad of passages with its own history. Why so? Crossroads are powerful sites of labyrinths for transferring our souls from one state to another. If we agree to this, our longing souls would be ready to return to Moissac; then we would transcend our ephemeral beings into our eternal ones, becoming unison with our Almighty God.

\section{REFERENCES}

1 Alberti Leon Battista. Ten Books on Architecture / ed. J. Rykwert, trans. J. Leoni. New York: Transatlantic Arts. 1966.

2 Hulme E. The Birth and Development of Ornament. London: Swan Sonneschein \& Co. 1894.

3 Cooper J. C. An Illustrated Encyclopaedia of Traditional Symbols. London: Thames \& Hudson. 1978.

4 Alberti. Ibid.

5 Hauglid R. Akantus fra Hellas til Gudbrandsdal (Akantus 1). Oslo: Riksantikvariatet. 1950. As my research is limited to the medieval times, acanthuses from the Renaissance and further are not explored in this paper.

6 Hearn M. F. Romanesque Sculpture. Oxford: Phaidon Press Limited. 1981.

7 Focillon $\mathrm{H}$. The Art of the West in the Middle Ages. Volume 1: Romanesque Art. Phaidon Press. 1963.

8 Ibid.

9 Schapiro M. The Romanesque Sculpture of Moissac. New York: George Braziller. 1985.

10 Hearn. Ibid.

11 Riegl A. Problems of Style: Formation for a History of Ornament / trans. E. Kain. New Jersey: Princeton University Press. 1893, 1992.

12 Kühnel E. The Arabesque: Meaning and Transformation of an Ornament / trans. R. Ettinghausen. Graz: Verlag für Sammler. 1949, 1977.

13 Ardalan N., Bakhtiar L. The Sense of Unity: The Sufi Tradition in Persian Architecture. Chicago: University of Chicago Press. 1973.

14 Wilson E. 8000 Years of Ornament. London: British Museum Press. 2000. 
15 Cooper. Ibid.

16 Schapiro. Ibid.

17 Burckhardt T. Art of Islam: Language and Meaning. World of Islam Festival Publishing. 1976.

18 Watson K. French Romanesque and Islam: Andalusian Elements in French Architectural Decoration c. 1030-1180. Oxford: BAR International Series. 1989.

\section{LITERATURE}

1. Al-Andalus, the Art of Islamic Spain / ed. J. Dodds. New York: The Metropolitan Museum of Art. 1992.

2. Alberti Leon Battista. Ten Books on Architecture / ed. J. Rykwert. trans. J. Leoni. New York: Transatlantic Arts. 1966.

3. Ardalan N., Bakhtiar L. The Sense of Unity: The Sufi Tradition in Persian Architecture. Chicago: University of Chicago Press. 1973.

4. Burckhardt T. Art of Islam: Language and Meaning. World of Islam Festival Publishing. 1976.

5. Burman T. E. Religious Polemic and the Intellectual History of the Mozarabs, C. 1050-1200. Leiden: E. J. Brill. 1994.

6. Cooper J. C. An Illustrated Encyclopaedia of Traditional Symbols. London: Thames \& Hudson. 1978.

7. Droste T. Die Skulpturen von Moissac. München: Hirmer Verlag. 1996.

8. Durliat M. "L'eglise abbattiale de Moissac des origins à la fin du Xie siècle". in Cah. Arch. 15.1965.

9. Focillon H. L'art des sculpteurs romans: recherches sur l'histoire des forms. Paris: Presses universitaires de France. 1964.

10. Focillon H. The Art of the West in the Middle Ages. Volume 1: Romanesque Art. Phaidon Press. 1963.

11. Frutiger A. Signs and Symbols. London: Studio Editions. 1989.

12. Gombrich E. The Sense of Order: A Study in the Psychology of Decorative Art. London: Phadion Press Limited. 1979.

13. Hamlin A. D. F. A History of Ornament, Ancient and Medieval. New York: Century Co. 1916.

14. Hauglid R. Akantus fra Hellas til Gudbrandsdal (Akantus 1). Oslo: Riksantikvariatet. 1950.

15. Hearn M. F. Romanesque Sculpture. Oxford: Phaidon Press Limited. 1981.

16. Hillenbrand R. Islamic Architecture - Form, Function and Meaning. Edinburgh University Press. 1994.

17. Hulme E. The Birth and Development of Ornament. London: Swan Sonneschein \& Co. 1894.

18. Kühnel E. The Arabesque: Meaning and Transformation of an Ornament / trans. R. Ettinghausen. Graz: Verlag für Sammler. 1949, 1977.

19. Riegl A. Problems of Style: Formation for a History of Ornament / trans. E. Kain. New Jersey: Princeton University Press. 1893, 1992.

20. Rupin E. L'abbaye et les cloîtres de Moissax. Paris: Treignac u. Montauban. 1987.

21. Schapiro M. The Romanesque Sculpture of Moissac. New York: George Braziller. 1985.

22. Speltz A. Styles of Ornament. London: Bracken Books. 1996.

23. Stierlin H. The Romanesque: Towns, Cathedrals and Monasteries. Köln: Taschen. 2001.

24. Watson K. French Romanesque and Islam: Andalusian Elements in French Architectural Decoration c. 1030-1180. Oxford: BAR International Series. 1989.

25. Wilson E. 8000 Years of Ornament. London: British Museum Press. 2000.

Images of acanthus and its capitals are downloaded from Sacred Destinations, Wikepedia, etc. 
Hee Sook LEE-NIINIOJA

\section{RELIGIJOS IR İVIRIŲ KULTŪRỤ ITAKA MUASAKO ŠV. PETRO ABATIJOS ARKADŲ MOZARABIŠKIEMS KAPITELIAMS}

\section{S a n tra u k a}

Mozarabiškąji meną kūrẻ krikščionys Pirènų pusiasalyje, kai jị $711 \mathrm{~m}$. užkariavo musulmonai. Šis menas sieja dvi tradicijas - krikščioniškajị turinị ir islamiškajam stiliui būdingus dekoratyvinius elementus bei formas. Dèl mozarabų emigracijos ị šiaurę islamo įtaka architektūroje per Santjago de Kompostelos piligriminius kelius plito tolyn į Europą. Santjago de Kompostelos piligriminiai keliai turẻjo didelę reikšmę religiniams ir kultūriniams mainams vèlyvaisiais viduramžiais.

Akantas - Viduržemio jūros regiono augalas dygliuotais lapais. Jo stilizuotu atvaizdu korintiniai kapiteliai buvo dekoruojami nuo graikų-romènų laikų. Nors pirmieji akanto atvaizdai graikų monumentaliajame mene, dažniausiai ant laidojimo urnų, ịtvirtino akantą kaip mirties ir gedulo simbolị, bet jo ornamentinès savybès arabeskos forma ilgai išliko populiarios net ir islamo kultūroje. Romaninio stiliaus statiniuose ypač svarbios struktūrinès kolonos dèl iškaltų raižinių, kuriuos Bažnyčia naudojo ugdydama gausią, bet daugiausia neraštingą liaudị. Puikiausias to pavyzdys - Prancūzijoje, Muasake, netoli piligriminių kelių, esanti Šv. Petro abatijos bažnyčia. Šv. Petro abatijos bažnyčioje išlikę seniausi romaniniai kapiteliai (1100 m.). 46 iš 76 kapitelių atspindi biblinius ar šventujų gyvenimo siužetus. Kiti 30 kapitelių dekoruoti gèlių motyvais. Penki mozarabiško stiliaus akantai panašūs ị aptinkamus gretimose bažnyčiose. Kaip žinoma iš istorijos, Muasako skulptūros turèjo ịtakos kitoms bažnyčioms, tai lème Prancūzijos ir Ispanijos meno glaudžius ryšius. Romaninių kapitelių kūrimą netiesiogiai veikè ir ịvairūs kontaktai: vedybiniai ryšiai, vizitai, vertimai ir kt.

Palyginus penkis mozarabiškus kapitelius Muasake su kapiteliais kituose statiniuose netoli piligriminiu kelių, nustatyta, kad šie kapiteliai buvo sukurti kūrybingų vietinių skulptorių, kuriuos ịkvėpé mozarabai ir islamiškosios arabeskos. Be to, akantas atlieka ne tik simbolinę, bet ir estetinę funkciją. Šie faktai rodo, kad vèlyvaisiais viduramžiais ties piligrimų keliais esančių šventyklų architektūrą veikè glaudūs religiniai ir kultūriniai kontaktai. Ši religijų bendrystè ir šiandienos konfliktuojančioje visuomeneje galètų paskatinti dialogą tarp ịvairių požiūrių ir ịsitikinimų.

PAGRINDINIAI ŽODŽIAI: akantų kapiteliai, Muasako Šv. Petro abatijos bažnyčia, mozarabiškas, romaninis, tarpkultūrinis.

KEY WORDS: Acanthus capitals, Cloister of the Saint-Pierre Abbey Church in Moissac, Mozarabic, Romanesque, Intercultural.

Hee Sook LEE-NIINIOJA - kaip viena pirmụjų azijiečių doktorantūros studenčių Skandinavijoje 8-ajame dešimtmetyje, dr. Hee Sook Lee-Niinioja specializuojasi teksto bei vaizdo ir hinduistinès, budistinès, krikščioniškosios bei islamiškosios architektūros ornamentacijos srityse. Ji studijavo žurnalistiką, vizualinę komunikaciją, meną ir architektūrą, taip pat religiją, kultūrą ir kalbą visame pasaulyje. Siekdama paskatinti tarpreliginị dialogą, ịsitraukè ị humanitarinę veiklą, dirbo mokytoja savanore Suomijos diplomatinėse misijose. Ji taip pat yra menininkè, dizainerè, žurnalistè, mokslininkè, bendradarbiauja su ICICH-ICOMOS.

Hee Sook LEE-NIINIOJA - PhD. As an Asian pioneer student in Scandinavia in 1970s, Dr. Hee Sook LeeNiinioja is specialized on Text-Image and Hindu-Buddhist/Christian/Islamic architectural ornamentation. She studied journalism/visual communication/art and architecture, as well as religion/culture/language across the globe. She volunteered humanitarian work and teaching as a member of the Finnish diplomatic mission abroad, hoping to enhance dialogues between religions. She is an artist/designer/journalist/scholar, engaged with ICICH-ICOMOS. 